\title{
Hubungan Health Belief Model pada Perilaku Prevensi saat Pandemi Covid- 19 di Kalangan Dewasa Awal
}

\author{
SENO WAHYUSANTOSO \& ACHMAD CHUSAIRI* \\ Departemen Psikologi Kepribadian dan Sosial, Fakultas Psikologi Universitas Airlangga
}

\begin{abstract}
ABSTRAK
Pandemi COVID-19 di Indonesia terus berkembang, dengan 79,6\% dari total kasus terdiri dari 18-45 tahun (per 20 Agustus 2020). Berbagai cara terus dikembangkan oleh ahli kesehatan untuk menekan angka penularan, salah satunya melalui pencegahan. HBM merupakan model yang kerap digunakan untuk memahami persepsi individu terkait perilaku kesehatan, termasuk prevensi. Penelitian dilakukan dengan survei online sebesar 231 responden, menggunakan alat ukur yang disusun dari awal untuk HBM serta alat ukur adaptasi untuk perilaku preventif. Studi menunjukkan hubungan signifikan HBM dengan perilaku preventif. Pada dimensi perceived susceptibility, perceived severity dan perceived benefit menunjukkan hubungan positif dengan perilaku preventif, sedangkan perceived barriers menunjukkan hubungan negatif dengan perilaku preventif. Ditemukan bahwa HBM adalah salah satu model yang dapat menggambarkan perilaku preventif saat pandemi, namun terdapat hal lain berupa tingkat pendidikan, selfefficacy, serta pengetahuan terhadap kondisi kesehatan tersebut. Penelitian memiliki berbagai kelemahan, yaitu sebaran kelompok usia yang tidak merata, serta kuesioner self-report yang rawan bias.
\end{abstract}

Kata kunci: health belief model, COVID-19, perilaku prefentif kesehatan

\begin{abstract}
COVID-19 Pandemic in Indonesia keeps on growing, with 79,6\% of the cases are within 18-45 years of age. Methods are developed by health officials to flatten the curve, including prevention. HBM is a model commonly used to understand how individuals perceive a health behavior, including preventive behaviors. Study conducted via online survey involving 231 subjects, using a scale to measure HBM, and adapted preventive behavior scale. Study shows that perceived susceptibility, perceived severity, and perceived benefit show positive correlation with preventive health behavior, while perceived barriers show negative correlation with preventive health behavior. It is found that HBM is one of the models that could describe how preventive health behavior in pandemic condition, but there is also education, self-efficacy, and knowledge about the health condition. There are some limitations to the study, such as uneven age group distribution, and self-report questionnaire method which is susceptible to bias.
\end{abstract}

Keywords: health belief model, COVID-19, preventive health behavior

Buletin Penelitian Psikologi dan Kesehatan Mental (BRPKM), 2021, Vol. 1(1), 129-136

*Alamat korespondensi: Fakultas Psikologi Universitas Airlangga, Kampus B Universitas Airlangga Jalan Airlangga 4-6 Surabaya 60286. Surel: achmad.chusairi@psikologi.unair.ac.id 
sehingga penggunaan, distribusi, reproduksi dalam media apapun atas artikel ini tidak dibatasi, selama sumber aslinya disitir dengan baik.

\section{PE N D A H U L U A N}

Semenjak COVID-19 mewabah secara global, setiap negara telah mengupayakan berbagai cara untuk menekan persebaran virus tersebut. Penekanan ini dilakukan melalui kebijakan-kebijakan yang mempromosikan perilaku preventif dalam melakukan kegiatan sehari-hari, berupa menggunakan masker, mencuci tangan, dan menjaga jarak dengan satu sama lain (WHO, 2020). Pencegahan merupakan kunci dari penurunan kurva penyebaran. Dengan penyebaran yang minim, persebaran kasus dapat terhenti, seperti pada negara Vietnam yang berhasil mengantisipasi persebaran virus dari sebelum ancaman tersebut datang (Our World in Data, 2020). Dari negara-negara di Asia Tenggara, Indonesia menempati peringkat kedua dalam pertambahan kasus per harinya, sebesar 2.266 kasus per 20 Agustus 2020, dengan total kasus sebesar 147.211 kasus (Worldometer, 2020). Di Indonesia, kasus COVID-19 didominasi oleh kelompok usia 19-45 tahun, yaitu sebesar 80\% (Gugus Tugas Percepatan Penanganan COVID-19, 2020), yang identik dengan kelompok usia dewasa awal yaitu usia 18-40 tahun.Menurut penelitian, terdapat banyak faktor yang mempengaruhi perilaku pencegahan pandemi (Bish \& Michie, 2010). Variabel demografis diyakini mempengaruhi bagaimana individu berperilaku. Variabel demografis yang dimaksud ialah usia, gender, dan tingkat pendidikan. Dalam pandemi H1N1, usia mempengaruhi perilaku, yaitu individu dengan usia yang lebih lanjut cenderung melakukan tindakan preventif berupa vaksinasi.

Menurut Barr dkk. (2008, dalam Bish \& Michie, 2010), individu yang lebih tua merasa lebih rentan terkena penyakit, yang kemudian mendorong mereka untuk mendapatkan vaksinasi. Namun, disebutkan juga bahwa mereka yang berusia 18-24 tahun lebih aktif dalam mengikuti anjuran pencegahan sederhana, seperti cuci tangan, menggunakan masker daripada mereka yang lanjut usia (Rubin dkk., 2009 dalam Bish \& Michie, 2010). Pada variabel gender, wanita lebih cenderung melakukan tindakan preventif daripada pria. Di Hong Kong dan Singapura, wanita cenderung melakukan tindakan pencegahan, seperti cuci tangan, menggunakan masker, serta tindakan kebersihan lainnya (Lau dkk., 2003; Leung dkk., 2003, 2004; Quah \& Hin Peng, 2004, dalam Bish \& Michie, 2010). Ini disebabkan oleh persepsi para wanita yang menganggap bahwa mereka lebih rentan terkena penyakit tersebut (Brug dkk., 2004, dalam Bish \& Michie, 2010). Dari temuan di atas, terdapat signifikansi perbedaan gender dalam melakukan perilaku sehat.

Untuk variabel tingkat pendidikan, temuan yang didapatkan sangat beragam. Dalam pandemi SARS, terdapat temuan yang menunjukkan bahwa semakin tinggi tingkat pendidikan, maka semakin tinggi kemungkinan individu melakukan tindakan preventif sederhana seperti mencuci tangan, memakai masker, serta perilaku kebersihan lainnya (Leung dkk., 2003, 2004, 2005; Tang \& Wong, 2004, dalam Bish \& Michie, 2010). Pada pandemi H1N1 di Inggris, hasil temuan berkata lain, dimana mereka dengan pendidikan yang lebih rendah cenderung melakukan perilaku avoidance (Rubin dkk., 2009 dalam Bish \& Michie, 2010). Temuan-temuan di atas tidak konsisten, namun secara keseluruhan dapat disimpulkan bahwa semakin tingginya tingkat pendidikan, maka semakin cenderung individu melakukan tindakan kesehatan.

Selain variabel demografis, di penelitian yang sama (Bish \& Michie, 2010), terdapat temuan yang menyatakan bahwa kegelisahan dan kepercayaan terhadap otoritas mempengaruhi kecenderungan tindakan preventif. Menurut Leung dkk., (2003, 2004, dalam Bish \& Michie, 2010), semakin tinggi tingkat kegelisahan, maka semakin besar kemungkinan melakukan tindakan pencegahan. Dalam

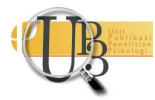


variabel kepercayaan terhadap otoritas, individu yang percaya bahwa pemerintah terbuka dalam berkomunikasi akan cenderung melakukan tindakan preventif. Perilaku pencegahan yang dimaksud adalah perilaku yang dianjurkan untuk mencegah penularan SARS, berupa mencuci tangan, memakai masker, mencuci alat makan, serta mengatur batuk, Selain itu, perceived susceptibility dan perceived severity mempengaruhi kecenderungan individu melakukan tindakan preventif pandemi (Park dkk., 2010). Apabila perceived susceptibility dan perceived severity yang dimiliki individu tinggi, maka kecenderungan individu untuk melakukan tindakan preventif akan semakin tinggi. Persepsi-persepsi individu akan kerentanan dan keparahan sebuah penyakit dapat membuat individu takut akan penyakit tersebut, sehingga individu lebih terdorong untuk melakukan perilaku preventif. Ditemukan bahwa perempuan cenderung memiliki tingkatan perceived susceptibility dan perceived severity yang lebih tinggi dari laki-laki, yang dimana perempuan lebih merasa rentan terhadap suatu penyakit. Perceived susceptibility dan perceived severity merupakan komponen dari health belief model, sebuah model yang digunakan untuk memahami faktor-faktor yang mempengaruhi individu dalam melakukan perilaku sehat.

Health belief model (HBM) adalah sebuah model yang dibuat pada tahun 1950, yang bertujuan untuk memahami mengapa individu kesulitan dalam mengikuti program pencegahan dalam konteks kesehatan (Rosenstock, 1974). HBM kemudian mengalami perkembangan dan adaptasi untuk penggunaan yang lebih luas terkait tindakan preventif individu terkait kesehatan, mulai dari pencegahan obesitas, pencegahan HIV/AIDS, serta pencegahan pandemi seperti H1N1 (Manika \& Golden, 2011; Jeong, et al., 2010; Park et al.,). HBM pun menjadi konsep yang umum digunakan untuk meneliti dan memahami perilaku sehat yang dilakukan masyarakat.

Terdapat berbagai penelitian yang menggunakan HBM untuk memahami perilaku preventif dalam kesehatan. Pada sebuah penelitian, ditemukan bahwa perilaku preventif dalam pandemi, termasuk H1N1 dan flu burung disebut berkaitan erat dengan komponen-komponen HBM (Miao \& Huang, 2012). Komponen yang dimaksud ialah empat komponen utama HBM, yaitu perceived severity, perceived susceptibility, perceived benefits, serta perceived barriers. Individu dengan perceived severity yang tinggi cenderung melakukan tindakan preventif, dikarenakan mereka sadar akan tingkat keparahan dari suatu penyakit, dalam konteks ini adalah H1N1. Individu dengan perceived susceptibility tinggi cenderung mengadopsi perilaku pencegahan, yang dimana individu merasa rentan/mudah tertular penyakit tersebut, sehingga individu terdorong untuk melindungi diri mereka. Selain itu, individu dengan perceived benefits yang tinggi cenderung mengadopsi tindakan preventif. Ini dikarenakan bahwa individu yang mempercayai akan manfaat dari sebuah tindakan akan lebih terdorong untuk melakukannya. Selain itu, perceived barriers juga dianggap suatu hal yang dapat mempengaruhi kecenderungan individu dalam mengadopsi tindakan preventif. Individu dengan hambatan/batasan dalam melakukan suatu perilaku preventif akan merasa kesulitan dalam melakukan tindakan tersebut. Dapat dikatakan bahwa individu dengan barrier yang rendah akan cenderung melakukan tindakan preventif. Keempat komponen HBM inilah yang kemudian dapat menjelaskan secara lengkap terkait kecenderungan individu dalam melakukan tindakan preventif selama pandemi.

Selain itu, Manika \& Golden (2011) mengungkap bahwa penggunaan informasi tentang ancaman terkait penyakit tertentu dianggap lebih efektif dalam memotivasi masyarakat melakukan perilaku preventif. Ini dibuktikan dengan data, bahwa semakin tinggi perceived threat/perceived susceptibility, maka semakin tinggi pula kemungkinan masyarakat melakukan tindakan pencegahan H1N1. Selain itu, pengetahuan pun juga mempengaruhi kemungkinan melakukan tindakan pencegahan. Individu yang lebih reseptif terhadap informasi, akan cenderung lebih memahami pandemi yang dihadapi, yang kemudian meningkatkan kemungkinan individu melakukan pencegahan. 
Dari berbagai penelitian yang sudah dilakukan sebelumnya, terdapat signifikansi HBM dalam melihat perilaku preventif persebaran pandemi. Komponen-komponen yang terdapat pada konsep HBM diyakini dapat menjadi acuan gambaran terkait bagaimana individu memandang tindakan preventif dalam konteks kesehatan, serta memahami faktor apa saja yang mendorong atau menghambat perilaku tersebut.

Secara umum diyakini bahwa seseorang akan bertindak untuk melakukan pencegahan, upaya mitigasi dan mengatur gaya hidup terkait kondisi kesehatan, mengacu pada health belief yang dimiliki (Rosenstock, 1974). HBM digunakan untuk menjelaskan konsep atas pemahaman perilaku individu. Perilaku yang dimaksud adalah perilaku kesehatan, baik dalam ranah preventif atau kuratif (Janz \& Becker, 1984). Dalam penelitian ini, perilaku yang akan dipahami berupa perilaku kesehatan dalam rangka menekan persebaran COVID-19. Kebijakan ini berupa pembatasan aktivitas, termasuk pembatasan sekolah, pembatasan bekerja, himbauan jaga jarak, hingga ibadah di rumah. Perilaku preventif COVID-19 ini akan dipandang melalui perspektif HBM. Dalam penelitian ini, peneliti akan menggunakan empat variabel utama dari HBM, yaitu perceived susceptibility, perceived severity, perceived benefits, serta perceived barriers (Abraham \& Sheeran, 2015). Penelitian ini mengajukan empat hipotesis, yaitu terdapat hubungan perceived severity HBM dengan perilaku preventif kesehatan selama pandemi COVID-19 pada dewasa awal (Ha1), terdapat hubungan perceived susceptibility HBM dengan perilaku preventif kesehatan selama pandemi COVID-19 pada dewasa awal (Ha2), terdapat hubungan perceived barriers HBM dengan perilaku preventif kesehatan selama pandemi COVID-19 pada dewasa awal (Ha3), serta terdapat hubungan perceived benefits HBM dengan perilaku preventif kesehatan selama pandemi COVID-19 pada dewasa awal (Ha4).

\section{Desain Penelitian}

\section{E T O D E}

Penelitian dilakukan dengan pendekatan kuantitatif, dengan jenis penelitian survei observasional analitik. Penelitian menggunakan jenis ini untuk menjelaskan bagaimana hubungan variabel independen dengan variabel dependen, dengan melihat apakah terdapat hubungan secara kuantitatif dari keempat dimensi utama HBM dengan perilaku prevensi saat pandemi COVID-19.

\section{Partisipan}

Partisipan dalam penelitian ini adalah kelompok usia dewasa awal, yaitu individu dalam rentang usia 18-40 tahun (Hurlock, 1986). Penelitian menyasar individu kelompok dewasa awal dikarenakan mayoritas dari mereka yang positif COVID-19 berada di kelompok usia 19-45 tahun (79,6\% dari keseluruhan angka positif). Penelitian ini memiliki karakteristik tertentu pada pemilihan subjek, maka dari itu peneliti menggunakan teknik purposive sampling. Purposive sampling digunakan untuk mendapatkan subjek sesuai dengan kriteria, maka dari itu jumlah populasi secara spesifik tidak diketahui. Penulis berhasil merekrut 231 partisipan $\left(M_{\text {usia }}=22.2 ; S D_{\text {usia }}=3.04 ; 61.9\right.$ persen perempuan $)$ yang sesuai kriteria, dengan sebaran subjek mayoritas di Pulau Jawa (98.3\%), dengan 45\% dari keseluruhan subjek dari Surabaya.

\section{Pengukuran}

Penelitian menggunakan survei daring berisi kuesioner self-report. Survei dilakukan melalui platform digital, yaitu Google Forms, yang berisi informed consent, informasi terkait biodata mencakup demografi partisipan, serta isian skala likert yang mengukur variabel-variabel yang diukur. Aitem dari isian tersebut diambil dari skala HBM-COVID untuk variabel independen, serta skala Clean and Contain yang

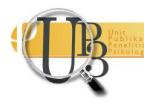


diadaptasi alih Bahasa. Survei disebar dengan meraih partisipan melalui media sosial dan aplikasi pesan singkat, dicantumkan tautan menuju survei tersebut.

Pengukuran variabel HBM menggunakan skala HBM-COVID yang dibuat peneliti, yang terdiri dari 54 aitem, dengan 4 pilihan jawaban (1="sangat tidak setuju", 4="sangat setuju"). Penghitungan reliabilitas dilakukan dengan teknik analisis Cronbach's alpha untuk keempat subskala HBM, yaitu perceived susceptibility, perceived severity, perceived benefits, serta perceived barriers adalah $.792, .765, .785$, dan .830, secara terpisah. Untuk mengukur variabel prevensi, peneliti menggunakan Clean and Contain Scale yang adaptasi dari Touissant dkk. (2020), sebanyak 9 aitem dengan koefisien reliabilitas yang cukup baik $(\alpha=.645)$. Dari hasil pengambilan data, skor total setiap subskala HBM-COVID dan Clean and Contain Scale dijumlah untuk kemudian digunakan sebagai bahan analisis dalam pengujian hipotesis. Untuk validitas alat ukur HBM-COVID, dilakukan Content Validity dengan menggunakan expert judgment, menggunakan isian CVI. Peneliti melakukan uji asumsi untuk melihat apakah asumsi-asumsi dasar tiap pengujian sudah terpenuhi. Dalam menguji normalitas, peneliti menggunakan teknik analisis Kolmogorov-Smirnov, dengan koefisien p sebesar .200 (p>.05), yang berarti normal. Selain itu, dilakukan juga set pengujian asumsi untuk uji regresi. Uji multikolinearitas yang sudah dilakukan menunjukkan bahwa variabel-variabel yang diteliti tidak menunjukkan multikolinearitas (perceived susceptibility, prevensi $=.493, \mathrm{VIF}=2.03$; perceived severity, prevensi $=.506, \mathrm{VIF}=1.98$; perceived benefits, prevensi $=.468$, VIF $=2.14$; perceived barriers, prevensi $=.578$, VIF $=1.73$ ). Untuk Uji DurbinWatson, data yang diujikan memenuhi asumsi independent errors (Durbin-Watson value $=1.61$ ).

Analisis Data

Pengujian hipotesis menggunakan Pearson Product Moment, Uji Regresi Linier, serta Analisis Power. Pearson Product Moment digunakan untuk melihat korelasi antar variabel independen dan dependen, yang kemudian dilanjutkan dengan uji regresi. Analisis Power dilakukan untuk melihat effect size dan power dari penelitian yang dilakukan. Perangkat lunak yang digunakan untuk menguji hipotesis ialah Jamovi for Windows versi 1.2.27 dan GPower versi 3.1.9.7.

\section{HAS IL PENELITIAN}

\section{Uji Korelasi}

Hasil Uji korelasi menunjukkan keempat variabel independen memiliki korelasi signifikan terhadap variabel dependen. Dimensi perceived susceptibility memiliki arah korelasi positif dengan korelasi yang cenderung sedang $(\mathrm{r}(231)=0.583 ; 95 \%$ CI $[0.491 ; 0.662] ; \mathrm{p}<0.001)$, perceived severity memiliki arah korelasi positif dengan korelasi yang cenderung agak lemah $\operatorname{lr}(231)=0.495 ; 95 \%$ CI [0.391; 0.587]; $\mathrm{p}<0.001)$, perceived benefits memiliki arah korelasi positif dengan korelasi yang cenderung sedang $(\mathrm{r}(231)=0.520 ; 95 \%$ CI $[0.419 ; 0.608] ; \mathrm{p}<0.001)$, serta perceived barriers memiliki arah korelasi negatif dengan korelasi yang cenderung agak lemah $(\mathrm{r}(231)=-0.418 ; 95 \%$ CI $[-0.519 ;-0.305] ; \mathrm{p}<0.001)$.

\section{Analisis Power dan Regresi Linier}

Setelah dilakukan analisis regresi linier, model yang digunakan cocok untuk menjelaskan data $(F(4$, 226) $=40.9 ; p<0.001 ; R^{2}=0.420$ ) dengan varians prediktor dapat menjelaskan 42 persen dari varians variabel dependen. Perceived susceptibility $(B=0.2493 ; 95 \%$ CI $[0.149 ; 0.348]$; $S E=0.356 ; t=4.94$; $p<0,001)$ memiliki pengaruh positif dan lemah. Perceived severity $(B=0.14 ; 95 \%$ CI $[-0.029 ; 0.31]$; $S E=0.116 ; t=1.63 ; p<0,105)$ memiliki pengaruh yang tidak signifikan. Perceived benefits $(B=0.1433 ; 95 \%$ CI [0.039; 0.247]; $S E=0.201 ; t=2.71 ; p<0.007$ ) memiliki pengaruh positif dan lemah. Perceived barriers

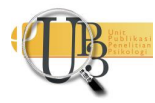


$(B=-0.055 ; 95 \%$ CI $[-0.115 ; 0.004] ; S E=-0.120 ; t=-1.81 ; p<0.072)$ memiliki pengaruh yang tidak signifikan. Untuk penghitungan statistical power, peneliti menghitung dahulu effect size dari penelitian ini. Setelah dilakukan penghitungan effect size $(f 2=0.724)$, peneliti menggunakan tingkat alpha sebesar $\mathrm{p}<0.05$. Analisis penghitungan power menunjukkan statistical power dari penelitian ini sebesar 1 .

\section{I S K U S I}

Subjek penelitian ini adalah individu dewasa awal, usia 18-40 tahun. Penelitian ini bertujuan untuk melihat apakah dimensi dari health belief model dapat menjelaskan perilaku preventif kesehatan selama pandemi berlangsung. Subjek berjumlah 231, namun mayoritas subjek berada di rentang usia 18-27 tahun, yaitu sebesar 95,2\% dari total subjek. Ditemukan bahwa mean skor perempuan lebih tinggi dibanding laki-laki dalam variabel prevensi. Selain itu, ditemukan juga bahwa profesi guru memiliki mean variabel prevensi tertinggi, diikuti oleh Aparatur Sipil Negara, Ibu Rumah Tangga, Pegawai Swasta, Mahasiswa, Pelajar dan Wirausahawan dengan skor terendah.

Dari hasil analisis data yang dilakukan, perceived susceptibility dan perceived benefit memiliki hubungan signifikan dengan perilaku preventif kesehatan. Selain itu, perceived severity dan perceived barriers tidak menunjukkan hubungan signifikan dengan perilaku prevensi. Dari empat hipotesis yang diajukan, dua hipotesis (H01 dan H03) gagal diterima, dan dua hipotesis (H02 dan H04) gagal ditolak. Temuan lain ditemukan dalam penelitian yang dilakukan Miao \& Huang (2012), dimana keempat dimensi utama HBM menunjukkan kaitan dengan perilaku preventif dalam konteks pandemi H1N1 dan flu burung.

Arah dari hubungan perceived susceptibility dan perceived benefits bersifat positif. Semakin besar perceived susceptibility (kerentanan terhadap penyakit), maka individu akan cenderung melakukan perilaku preventif. Ini dikarenakan rasa kerentanan individu akan suatu kondisi/penyakit yang kemudian membuat individu tersebut ingin menghindari/mencegah kondisi tersebut. Selain itu, semakin besar perceived benefit (manfaat dalam melakukan perilaku sehat), maka semakin tinggi kecenderungan individu untuk melakukan perilaku preventif kesehatan. Individu akan cenderung melakukan suatu perilaku sehat yang dirasa efektif untuk menghindari kondisi/penyakit yang tidak diinginkan.

Penelitian lain mengungkap bahwa terdapat faktor selain empat dimensi utama yang diungkap dalam penelitian ini. Dalam penelitian tersebut, ditemukan bahwa usia, pendidikan, pekerja kesehatan, serta perceived susceptibility, perceived benefits, perceived barriers dan self-efficacy memiliki kaitan dengan kecenderungan untuk melakukan perilaku preventif kesehatan (Barakat \& Kasemy, 2020). Dalam penelitian ini, perceived severity tidak termasuk dalam faktor pengaruh perilaku preventif dalam pandemi COVID-19. Disebutkan bahwa self-efficacy adalah kunci untuk mengatasi perceived barriers, agar individu lebih memiliki kepercayaan diri untuk mengendalikan hambatan yang dimiliki dalam berperilaku sehat. Selain itu, pendidikan subjek juga berpengaruh, semakin tinggi tingkat pendidikan individu, semakin besar kecenderungan untuk melakukan perilaku preventif. Ini dikarenakan pengetahuan akan suatu penyakit dapat meningkatkan kesadaran atas perlunya melakukan perilaku preventif. Dengan tingkat pendidikan yang lebih tinggi, individu dapat memahami informasi yang beredar di ranah umum lebih baik, salah satunya adalah tentang COVID-19.

Dalam penelitian lain (Niu, 2020), ditemukan bahwa kecenderungan individu untuk melakukan perilaku preventif kesehatan adalah orang yang menerima Pendidikan lebih tinggi, menikah, memiliki selfefficacy serta dukungan emosional yang tinggi serta mengikuti perkembangan berita tentang COVID-19, sebaliknya individu yang mempunyai penghasilan yang rendah, Pendidikan yang kurang memadai, 
memiliki self-efficacy dan dukungan emosional yang rendah, serta literatur digital yang buruk menyebabkan individu tidak melakukan perilaku preventif kesehatan.

Hasil lain ditunjukan dalam penelitian Shahnazi (2020),regresi berganda menunjukkan bahwa skor rata-rata perilaku pencegahan COVID-19 lebih tinggi pada perempuan dibandingkan laki-laki, dan lebih tinggi pada penduduk perkotaan daripada penduduk pedesaan. Selain itu, faktor self-efficacy menjadi salah satu prediktor untuk perilaku prevensi COVID-19.

\section{S I M P U L A N}

Berdasarkan hasil analisis data, maka dapat disimpulkan bahwa dimensi-dimensi HBM memiliki hubungan dengan perilaku preventif kesehatan pada kalangan dewasa awal, yaitu perceived susceptibility dan perceived benefits. Arah hubungan yang ditunjukkan oleh koefisien korelasi perceived susceptibility dan perceived benefits adalah positif, yang berarti semakin tinggi perceived susceptibility dan perceived benefit, maka semakin tinggi kecenderungan individu untuk melakukan tindakan preventif. Model regresi yang dibuat menunjukkan bahwa variabel-variabel prediktor menjelaskan $42 \%$ dari variabel dependen, dengan effect size sebesar 0.724 dan power sebesar 1.000 .

\section{U C A P A N T ERIMAKASIH}

Peneliti mengucapkan terima kasih atas bantuan dari kerabat-kerabat keilmuan yang telah membantu proses penelitian ini, terutama dalam proses adaptasi alat ukur hingga validitas alat ukur.

\section{DEKLARASI POTENSI TERJADINYAKONFLIK KEPENTINGAN}

Seno Wahyusantoso dan Achmad Chusairi tidak bekerja, menjadi konsultan, memiliki saham, atau menerima dana dari perusahaan atau organisasi manapun yang mungkin akan mengambil untung dari diterbitkannya naskah ini.

\section{PUSTAKA ACUAN}

Abraham, C., \& Sheeran, P. (2015). The Health Belief Model: Predicting and Changing Behavior. New York: McGraw-Hill.

Barakat, A. M., \& Kasemy, Z. A. (2020). Preventive health behaviours during coronavirus disease 2019 pandemic based on health belief model among Egyptians. Middle East Current Psychiatry, 43.

Bish, A., \& Michie, S. (2010). Demographic and attitudinal determinants of protective behaviours during a pandemic: A review. British Journal of Health Psychology, 50-62.

Gugus Tugas Percepatan Penanganan COVID-19. (2020, Agustus 20). Peta Sebaran COVID-19. Retrieved from Gugus Tugas Percepatan Penanganan COVID-19: https://covid19.go.id/peta-sebaran

Hurlock, E. B. (1986). Developmental Psychology: A Life-Span Approach. New York: McGraw-Hill.

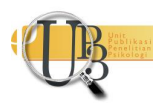


Janz, N. K., \& Becker, M. H. (1984). The health belief model: A decade later. Health education quarterly, 1-47.

Jeong, H. S., Lee, D. W., Youn, C. H., Lee, M. K., Lee, S. J., Suh, Y. S., \& Kim, D. H. (2010). Perception and Performance of Preventive Behaviors for the Pandemic Influenza in Hospital Employees and Outpatients. Yonsei Medical Journal, 181-187.

Manika, D., \& Golden, L. L. (2011). SELF-EFFICACY, THREAT, KNOWLEDGE AND INFORMATION RECEPTIVITY: EXPLORING PANDEMIC PREVENTION BEHAVIORS TO ENHANCE SOCIETAL WELFARE . Academy of Health Care Management Journal, 31-44.

Miao, Y.-Y., \& Huang, J.-H. (2012). Prevalence and associated psychosocial factors of increased hand hygiene practice during the influenza A/H1N1 pandemic: findings and prevention implications from a national survey in Taiwan. Tropical Medicine \& International Health, 604-612.

Niu, Z. W. (2020). Chinese Public's Engagement in Preventive and Intervening Health Behaviors During the Early Breakout of COVID-19: Cross-Sectional Study. Journal of medical Internet research, 8.

Our World in Data. (2020). Emerging COVID-19 success story: Vietnam's commitment to containment. Our World In Data.

Park, J.-H., Cheong, H.-K., Son, D.-Y., Kim, S.-U., \& Ha, C.-M. (2010). Perceptions and behaviors related to hand hygiene for the prevention of H1N1 influenza transmission among Korean university students during the peak pandemic period. BMC Infectious Diseases.

Rosenstock, I. M. (1974). Historical origins of the health belief model. Health education monographs, 328335.

Shahnazi, H. A.-L. (2020). Assessing preventive health behaviors from COVID-19: a cross sectional study with health belief model in Golestan Province, Northern of Iran. . nfectious.

WHO. (2020, June 4). Coronavirus disease (COVID-19) advice for the public. Retrieved from World Health Organization Website: https://www.who.int/emergencies/diseases/novel-coronavirus2019/advice-for-public

Worldometer. (2020, Agustus 20). COVID-19 Coronavirus Pandemic. Retrieved from Worldometer: https://www.worldometers.info/coronavirus/\#countries 